\title{
Arabic Facts in Palestine: Clashing Hybridities in Transnational Cultural Production
}

SAMER AL-SABER

In 2012, Bethlehem's Al-Rowwad Cultural and Theatre Society undertook the challenge of co-producing Arthur Milner's Facts with the New Theatre of Ottawa for a nine-city tour in the region. The successful production and warm reception to the play highlighted the potential for more Canadian playwrights, companies, and artists to engage with Palestine through cultural and theatrical exchanges. It also highlighted a series of challenging political, cultural, and philosophical differences, which emerged in production, talkbacks, and audience reception. Palestinian communities in different cities reacted in remarkably different ways to the play, which tells the story of two Israeli and Palestinian investigators as they attempt to solve a murder mystery in the West Bank. In Bethlehem, political issues of security coordination between the Palestinian Authority and Israel dominated the discussion. In Hebron, the audience responded to the engagement with settlers and the predominant presence of the Goldstein massacre at the end of the play. The mixed Israeli-Palestinian audience in Jaffa reacted in similar ways to the Canadian audience in Ottawa, focusing on the rift between religious and secular Israel. These varied responses reflected the transnational dimension of the production: the Canadian origins of the play, its hybridity in production, its international appeal, and its relevance to Palestine. I will outline the challenges of the production through a description, analysis, and critique of the process that led to opening night in Bethlehem's Dar Annadwa Addawliyya, and closing night at Al-Rowwad. From the checkpoint to closing night, I tell the story of a successful partnership, while revealing the inevitable clashes of values that took place in this transnational cultural production.

In narrating my experience as the director of the production, I draw on contested concepts such as transnationalism, hybridity, and modernity without defining them, a frustrating condition for the reader of an academic journal. Although I hope that these concepts may be enriched by the documentation of this production, I describe some of the challenges in this journey not for the purpose of theoretical development, but to identify a space between what we think we are doing and what we actually are doing. In transnationalism and through hybridity, this theatrical production enters an alternative space that simultaneously belongs to Canadians, but doesn't. By travelling to an alternative geography, this play became an exploration ground for multiple clashing and complementary identities and values. The dislocation of the cultural production from its indigenous home and relocation to the address of its characters became the catalyst that contested and temporarily disrupted its/our legitimacy. 


\section{Facts in Ottawa}

Arthur Milner's play investigates the issue of Israeli settlements in the West Bank through the lens of religious conflict and the institution of archaeology. Produced in Canada in 2010 , the play presents a Jewish-Canadian playwright's examination of the conflict in three perspectives: a secular Israeli investigator, a Palestinian Authority investigator, and a right wing Israeli-American settler in Hebron. The two investigators, Yossi and Khalid, must work together to solve a murder mystery, in which the primary suspect is the settler, Danny. The following question drives the plot of the play: Did Danny murder an American archaeologist in Hebron? However, the underlying dramatic question throughout the play is whether a Palestinian and an Israeli can cooperate in the investigation, despite their deep-seated conflict over the creation of the state of Israel in Palestine in 1948, the ensuing events leading to the occupation of 1967 , and the Israeli expansion into the West Bank through the systematic building of settlements, a substantial Israeli investment in urban planning, and the ongoing exploitation of resources in occupied territories. The secular Israeli official and his Palestinian counterpart must temporarily make peace in order to bring a settler to justice.

When I attended the initial production at the Great Canadian Theatre Company (GCTC) in Ottawa, I observed an emphasis on the conflict between the emerging right-wing religious settler movement, represented by the unwavering Danny, and the shrinking Israeli secular left, represented by Yossi. This directorial emphasis heightened the confrontations between the two characters. Yossi grew more determined to indict Danny, citing the settler movement's increasing fanaticism and near-impunity in the changing, possibly deteriorating, state of Israel. He explains the first generation Israelis' dream of a socialist state and Zionism's deterioration from a socialist-secular movement to an extremist religious one. Danny's conflict with the "Yossis" of Israel emanates from a religious Mandate: God gave the land of Abraham to the Jews, thus contemporary ideas on equality and human rights do not belong in governance. In the Ottawa production, the conflict culminated in Yossi killing Danny in a manufactured moment designed to appear like self-defense. In this conflict, the Palestinian character and his cause appear suitably impotent. Khalid becomes an observer to the conflict as Israel's power players negotiate their differences within a Zionist framework.

\section{Obstacles: Towards A Production in Palestine}

In spring 20II, Milner met with the administrative and artistic directors of the Palestinian National Theatre in East Jerusalem. After an initial co-production agreement, Martin Conboy and I joined the team as the production designer and director, respectively. Subsequently, artistic director Kamel El-Basha and I began our collaboration on the production. Having seen his work as an actor on stage, I asked him to consider playing the role of Yossi. We then discussed his upcoming translation of the play into Arabic and identified a number of obstacles to producing the play in Palestine.

First, in the contemporary Palestinian context, the play could potentially be received as a peace building and security coordination propaganda project. Since the Oslo Accords of I993, Palestine has been flooded with international funds intended to build dialogue and construct a coexistence framework in the daily lives of Israelis and Palestinians. ${ }^{\mathrm{I}}$ Projects 
such as Seeds of Peace, Ta'ayush (coexistence), and Oseh Shalom (make peace) have failed to alleviate Palestinian suffering or to improve quality of life in East Jerusalem and the Occupied Territories. ${ }^{2}$ Security coordination between the Israeli Military and the Palestinian Authority had become increasingly seen as a mechanism of entrenching the occupation and subduing Palestinian resistance. ${ }^{3}$ Theatrical collaborations such as Romeo and fuliet between Al-Kasaba Theatre and Al-Khan Theatre failed to reach audiences in Israel as theatres boycotted the production for fear of retaliation from extremist right wing Israeli groups (George Ibrahim in Marina Kotzamani 35). In this transnational context, the premise of the play that an Israeli and a Palestinian would collaborate to solve a murder case could be seen as Western/Israeli propaganda, whereas in the Canadian context it was seen as a sign of healthy political dialogue. Canadian audiences reacted in line with the prevalent Euro-American tendency to view the Israel/Palestine conflict through the lens of peace building and conflict resolution. In the Western/Canadian context, the quest for "peace" is not only positively fetishized, but also funded through cultural and social programs that amount to a "peace industry." 4 Although Milner's Facts did not promote this narrow perspective, the collaboration between an Israeli and a Palestinian onstage in this highly sensitive context could unintentionally give the appearance of a "co-existence" project.

Second, the translation of plays into Arabic presents a host of challenges that theatre makers rarely face in Canada. Facts could be translated directly into classical Arabic (Fusha) or into colloquial Arabic ('ammiya) but both options presented their own sets of difficulties because the characters speak both Hebrew and Arabic although the play is originally written in English. Within classical Arabic, the characters could speak in an elevated language that could approach verse, but they could also speak media Arabic, which holds to the structure of the language but simplifies the grammar. Fusha has the advantage of pan-Arab accessibility, ease of publication in print, and the absence of dialects in production. But the specific ethnic and geographic origins of the characters would not be very easily communicated in Fusha, which functions as a lingua franca in Arab countries.

'Ammiya presented the possibility of speaking in localized dialects. The Palestinian character, Khalid, would necessarily speak in a Hebronite accent, but how would El-Basha's Arabic script communicate Yossi's Hebrew into a Tel Aviv accent and Danny's manner of speaking as an American settler? How would the production distinguish between their speaking in regional Hebrew and in their own version (idiolect) of Arabic on different occasions? What about Danny's non-native Hebrew? In the original text of the play, English provided a neutral and distant lingua franca that could be coloured by regional influences and actors' choices of characterization, but neither form of Arabic could present a similar foundation. In addition, the choice of language presented a political issue for Palestinian audiences. Although they could appreciate the use of the vernacular, how would they react to Israeli characters as they spoke in a Palestinian accent? At an instinctual and purely reactionary level, I struggled with the possibility of hearing anti-Palestinian arguments and racist epithets spoken in my own language and dialect. After several deliberations with El-Basha, we chose the more pragmatic 'ammiya because it reflected the informality and humour in Milner's dialogue.

Third, each Palestinian site of cultural production poses challenges that vary based on geography, political status, governing authority, cost of living, and theatrical tradition. 
A production at the PNT in East Jerusalem would provide a different set of advantages and disadvantages as compared to Al-Rowwad in Bethlehem, Al-Midan Theatre in Haifa, AlKasaba Theatre in Ramallah, or the Freedom Theatre in the Jenin refugee camp. Although the centrality of occupied East Jerusalem would prove advantageous for touring, the city's high cost of living, limited access for actors and audiences, and potential risk of theatre closure by the Israeli authorities were unattractive for theatrical production. Yet, the PNT's tradition as a premiere production house during the period of El-Hakawati in the I980s had equipped the theatre with experienced staff, facilities, and mechanics of technical production. The National Theatre also lent Facts a prestigious credibility in Palestine and internationally. Finally, touring throughout Palestine from East Jerusalem necessitated the casting of Palestinian actors, who held Israeli passports or blue permanent residency identity cards in order to cross the checkpoints of the Israeli military.

\section{The PNT Fails}

In late 2OII, the PNT underwent a series of administrative changes. Theatre director Jamal Ghosheh resigned his position after the eruption of a series of longstanding disagreements with staff and local artists. Artistic Director Kamel El-Basha, who managed the Facts project, was heavily involved in internal negotiations with the board of directors. By the end of the year, El-Basha was asked to resign as well. He continued his duties at the theatre without compensation for a number of months thereafter. Milner, Conboy, and I asked him to remain with the production as project manager and actor. During this period of transition, Facts proved to be an unprofitable prospect. The theatre was responsible for providing rehearsal space, technical expertise, staff, facilities, administrative support, publicity, and internal salaries. Arthur Milner and the New Theatre of Ottawa were responsible for funding the Canadian team, actor salaries, and the tour. Milner had applied and received two grants from the Canada Council for the Arts: \$22,00o for the international coproduction and \$2900 for the translation into Arabic. He also fundraised an additional \$20,000 from an email campaign, play-reading events in Toronto and Ottawa, and educational slide shows detailing his previous tour of the West Bank and the experience of Palestinian citizens of Israel. As the PNT lost its stability, the production in East Jerusalem progressively became more unlikely. The board of directors could no longer guarantee the availability of funds, space, or staff.

In the early months of 2012, we searched for a new partner. In conversation with ElBasha, we considered potential co-production with various theatres. In the new search criteria, I proposed approaching artistic directors who could both co-produce and act in the play. Edwar Muallem of Ramallah's Ashtar Theatre declined due to his theatre's commitments in Palestine and internationally. George Ibrahim of Al-Kasaba Theatre in Ramallah disagreed with the translation, the play's ending, and the budgetary approach of the production. Although the well-equipped Freedom Theatre in Jenin would have been an ideal partner, we reconsidered this possibility due to the theatre's inconvenient location in the far north of the West Bank and safety concerns after the assassination of artistic director Juliano Mer Khamis. In March 2OI2, one of our conversations proved to be most fruitful. Dr. Abdelfattah Abusrour of Al-Rowwad in Bethlehem's Aida Refugee Camp responded with enthusiasm. He and his theatre were available. The small budget fit the low cost of production associated with AlRowwad. The theatre could provide administrative support and volunteers as needed. I final- 
ized the casting of the play: El-Basha played the Israeli Yossi and Abusrour the Palestinian Khalid. Artistic director of East Jerusalem's Pocket Theatre Amer Khalil played the settler Danny. All three actors had the necessary permissions and identity cards to access the West Bank and Palestinian theatres in Jaffa and the Galilee. The incredible artistic and professional resources of these three actors made the production possible at the local level.

\section{Hybridity in Transnational Production}

In late August 20I2, on my way to East Jerusalem, I met with Conboy and Milner at Martin Conboy Lighting Design (MCLD) on Sparks Street in downtown Ottawa. Conboy and I had agreed to adopt his designs from the GCTC production; however, the same ground plan would bear a new conceptual framework.

I presented the collaboration between Yossi and Khalid as a product of the Oslo Accord's security coordination between Israel and the Palestinian Authority. Thus the overall atmosphere of the stage space would be riddled with symptoms of distrust and an inherently disproportionate power structure. Although the set would still depict a small meeting room in IDF offices, it would display Israel's advanced security apparatus through instantaneous communication tools and live video feeds from security cameras in Hebron. The non-descript room in the text would be upgraded to a "control room" that demonstrated Yossi's access and power. By contrast, Khalid would arrive with a thick file of documents and his frustration from months of unfruitful personal efforts to solve the murder case. Despite Khalid and Yossi's previous investigative work together, I saw them as adversaries. Conboy suggested that the relationship could be an opportunity to present moments of revelation. For example, Khalid might steal a glance at a security monitor or Yossi might copy a flash drive belonging to Khalid. We discussed the possibility of showing Khalid on camera being searched at the entrance of the IDF's establishment. Milner wholeheartedly objected to the concept as counterproductive to the minimal requirements of the script. Believing the concept subverted the text, he explained, "Yossi would start the play from a position of distrust." I replied, "I am not interested in directing an Israeli/Palestinian buddy flick." Despite our similar views on the larger political context, this disagreement over my directorial interpretation and my vision for the character of Yossi remained unresolved throughout the production process.

Milner wrote Yossi as a secular Jew from Tel Aviv. An extraordinary modernist, Yossi perceived Israel as a socialist project. Yossi's Israel embraced science, culture, liberalism, and equality. But over time, it began its decline to become a religious society heavily influenced by extremist settlers and right wing groups, represented in the play by Danny. Since his inception of the play, Milner frequently stated, "I am Yossi." Milner identified with the character's Ashkenazi heritage, age, and cultural affinities. In fact, Yossi was Milner's response to his father's radical Zionism. Milner's parents were "Polish Jews who narrowly escaped the holocaust" (Milner vii). His father "had been a Zionist from an early age" and an associate of the Herut and Israeli prime minister to be, Menachem Begin (vii). Over time, Milner grew more critical of Israel. In 1990, he wrote his own critique of Zionism in a one-person play called Masada, which his father did not see and would have disagreed with. In Facts, Milner explored his interest in biblical archaeology and Israeli-Palestinian relations. On his disagreement with his father, he stated: "I am convinced that he was wrong, even dangerously so, but he was not evil" (vii). 5 
Milner and I have often agreed on many - possibly most-issues related to the creation of Israel and the occupation of Palestine. However, our respective subject positions often produced artistic disagreements. Seeing through a Palestinian lens, I intended to direct a production that emphasized the most current conversations on the Palestinian street. Given the sensitive issues of security coordination and the impunity of Israeli settlers, I conceived of the production as a fictional but revealing account of inaccessible discussions behind closed doors. The intellectual argument between Yossi's secularism and Danny's fundamentalism remained an integral component of the production; however, my interpretation emphasized the power disparity between the Israeli occupiers (Danny and Yossi) and a single Palestinian investigator in Israel's military establishment. The production presented the collaboration as a necessary condition of the occupation for Khalid. It further suggested that the theatrical script presented a living portrait of the interactions between Palestinian and Israeli investigators. I believed in the necessity of addressing the possible criticism that the play promoted security coordination. Milner rejected the need for defending the production against an issue that he did not write or intend. In his final report to donors, Milner reflected on our disagreement after the end of the tour:

On the whole, I don't think the audience bought the criticism or the defense. Facts shows an honest, intelligent Palestinian cop getting along quite well with a liberal Israeli cop, collaborating on a case that has nothing to do with suppressing Palestinian dissent. If there is security co-ordination here, it is of the most informal and benign sort. (Milner, Final Report) ${ }^{6}$

Shortly after the run of the show had begun, a fellow Palestinian director approached me in the meeting room of a Ramallah theatre. He said: "You know, many questions surround your production." I replied: "I know." He referred to the internal conversation among theatre artists and audience members, who questioned the wisdom of a production that potentially reinforced a false image of coexistence. Another artist stated in confidence after reading the play, "It is a good play, but why are the Palestinians doing Israel's dirty work? This play should be staged in Tel Aviv for Jews." I explained the production's emphasis on security coordination and power disparity. She was temporarily appreciative. After she saw the production, she called me on the phone: "I am not convinced it worked." Although these criticisms challenged the premise of collaboration in the play, they do not erase the positive response to our production. The depth of Milner's negotiation of interpersonal relationships and his exploration of the impunity of West Bank settlers received accolades in nearly every talkback session with the audience. In Ramallah, one audience member remarked: "How is it possible that a Canadian could represent our situation with such complexity?"

One hybrid identity played a significant role in ingratiating the Canadian team to Palestinians. Martin Conboy's Irish heritage and experience provided common grounds that linked the occupation of Ireland to the colonization of Palestine. Standing on the roof of AlRowwad theatre in the Aida Refugee camp, Conboy confided in me, "I look at the roofs of all these buildings and I think myself in Dublin. This is the Ireland I grew up in." He had built a unique friendship with our technical director, Ramsey Alsheikh Qassem, who also held the position of resident lighting designer and technician at the PNT. With the help of puppet artist and set builder Abdelsalam Abdo, he adapted Conboy's designs to suit local 
materials and assure portability into various touring sites and across checkpoints. Conboy often commented on the improvisations of the technical team and the affordability of their techniques: "We could never do this in Canada!" Inversely, he gained their respect. Referring to Conboy, Qassem told me: "We get many foreign designers, who dictate to us their implementation of theatrical designs. They are rarely successful. We know our space, our country, our problems, and our materials. This designer? He's a good man!" Conboy had wisely deferred to Qassem and Abdo's expertise throughout the set building process.

\section{The City as Transnational Space}

As the production travelled to different cities, Palestinians reacted in different ways, suggesting that transnational experiences took place within the complex Palestinian society. On 26 September 2012, the play opened at Dar Annadwa Addawliyya. The team arrived a few days earlier to avoid the checkpoint closures of Yom Kippur on 25 September 2012. A tense political atmosphere had been escalating as protests occurred almost daily throughout the month (Kershner A6). Taxi drivers went on strike to protest high gas prices and the rising cost of living. Government workers protested delays in their salaries. Demonstrators called on the Palestinian authority to end its economic and security agreements with the state of Israel. Rehearsals leading to opening night had been tense, as the show was not yet ready for a public showing. In the post-show discussion after a mostly successful first performance, a professor at the Dar Al-Kalima College asked: "Given that security coordination is a relevant topic at the moment, how do you believe this show addressed the question?" Another professor and activist asked for an elaboration on my own director's notes, which stated:

I protest. I object. I condemn. I disagree. I accuse:

Normalizer! Collaborator! Traitor! I yell: Boycott! But the FACTS on the ground never change.

Facts: Security coordination. Settlements. Checkpoints. No state. No economy. No security. Facts: Oslo happened. Oslo destroyed. Oslo dismantled the fabric of Palestinian society.

Facts: A nightmare fills the surface and rotten politics flourish out of sight.

A play. Fiction. Reality. Fiction. Murder. Archaeology. Ideology.

Collaboration. Unequal partnership. The limits of Palestinian liberalism. The limits of Israeli leftism. The limits of nationalism.

To see nuances. To see truths. To see facts. Facts exist in the mirror. Facts exist in the theatre.

A fictional world tells us what happens behind closed doors. (Al-Saber)

Various members of the team, myself included, responded by explaining the concept of the production as presenting a snapshot of coordination behind closed doors rather than propagandizing joint Israeli/Palestinian Authority ventures. I was particularly vehement in my defense of the play and its interpretation not only as a murder investigation in the context of settler colonialism, but also as a revealing portrait of unseen interactions between the Palestinian Authority and the Israeli military.

In Jaffa, we presented the play at the Palestinian Al-Saraya theatre, which operates under the umbrella of the Arab Hebrew Theatre Center in the old city. The municipality of Tel Aviv annexed the Palestinian city of Jaffa in its entirety by 1950. Despite the ongoing Israeli 
gentrification and coexistence efforts, the city remains a contested site and a constant reminder of the 1948 Nakba. The majority audience of Palestinian citizens of Israel responded to the complexity of inter-Jewish relations in the play. Unlike the performances in the occupied West Bank and Golan Heights, audience members commented at length on the conflicting identities within Israel.They perceived Israel's image of liberal secularism and right wing religious Zionism as the crux of the play, and by extension, the state's problematic national identity. Without a doubt, the audience's position as Christian and Muslim Palestinian nationals under the governance of a Jewish majority provided the framework for this transnational distinction.

Hosted by Yes Theatre in the West Bank city of Hebron, an audience composed of families including their young children responded primarily to the presence of a settler character on stage. As children entered and exited the theatre at will during the performance, the play's investigation of a murder in Hebron caught the attention of the adults. They recognized the map of their city and the settlers referenced in the text as a nonfictional presence in the currently besieged Al-Shuhada Street and the neighboring settlements. Since religious settlers have taken residence in Hebron, Danny's entrance in religious costume apparels such as a Kippah and Tzitzit appeared familiar. When Khalid revealed the death of his family members in the Goldstein massacre, the audience went silent. ${ }^{7}$ In the post-show talkback session, one parent commented on the historical necessity of addressing the massacre on the Palestinian stage: "A whole generation of young Palestinians has not witnessed this event." Suggesting the possibility of touring the play in schools, he saw the production as an opportunity to memorialize the massacre.

\section{In retrospect...}

As I recall the history of this production, one moment encapsulates my struggles with the text and my experience as director. Before its GCTC staging, Milner and I had a number of conversations about the script. In one instance, I objected to the following dialogue:

Yossi: We are peasants. Speaking on behalf of my people. We Zionists had ambitions, we embraced socialism and science. But Israel is full of peasants who worship and idolize. And the Palestinians?

Khalid: We were on our way.

Yossi: To what?

Khalid: To modernity.

In this exchange, Milner adopts a rational liberal humanist belief that a universal modernity exists. He looks at Palestine from the outside, evaluating the historical moment from his own lens. His character, Khalid, recognizes this modernity and not only does he believe it to be attainable, he also declares that the Palestinian people have yet to reach it. As a Palestinian, an Arab, I reject the concept of a universal modernity as a colonial construction. Milner chose to keep the exchange. In the Arabic production, we struggled with the translation. El-Basha noted that a direct translation presents a Western academic concept, in which most of the audience would not be conversant. Instead, he used the word for civilization, "Al-Hadara."That choice implied an Orientalist viewpoint. Actor Abdel Al-Fattah Abu Srour suggested "inde- 
pendence," but the ensuing dialogue on Judeo-Christian modernity no longer made sense. As a rehearsal team, we failed to solve the problem of this Palestinian character negotiating a nonindigenous philosophical stance. In every performance, Abu Srour experimented with a different translation of the concept. He eventually returned to the direct equivalent of the word modernity: Al-Hadatha. Western philosophy persisted on stage, only to be understood by those who cared to study it.

This intellectual disagreement between Milner and me reveals an inevitable clash of values. Milner sought to produce Facts in Palestine to be witnessed by the people he wrote about. I planned to direct a Palestinian production that emphasized the most pressing issues for Palestinians. Both intentions represented our subject positions and our own form of activism as artists. In the end, neither of us succeeded in convincing the other, but the resultant hybrid production found an interested audience in Palestine, sometimes in the least expected places. Our associate producer, Daniel Daley, described the energy at the performance in the Jenin refugee camp: "[A]t Jenin's Freedom Theatre, the excitement was palpable in a room full of young Palestinian men under the age of $2 \mathrm{r}$ " (Daley). At every performance in every city, the play and the production's complexity provided a platform for political debate and an opportunity to critique the status quo. In 20I4, the play was remounted in Bethlehem, Ramallah, and East Jerusalem. In the process of re-rehearsing it, the Palestinian actors found their own version of the production, highlighting their own struggles with the text and everyday grind of living under occupation. But this success won't take away a peculiar reality: although Facts may find a well-deserved place in the modern canon of Canadian theatre, it will not find such a place in Palestine because such a canon and its associated modernity cannot exist. Although the subject of the play remains topical in Palestine, Western modernity is not indigenous to the land.

The gap between our intention-as actors, production team, author, designer, and director-and our final action still haunts me.

\section{Notes}

I For example, in Narrative and the Politics of Identity, Phillip L. Hammack concludes: "the cosmopolitan foundations of American-based programs are misguided, in fact, problematic" (355).

2 For a personal narrative that addresses the question of co-existence and dialogue programs, see Sami Al-Jundi's personal account of his experience with Seeds of Peace in The Hour of Sunlight, cowritten with Jen Marlowe.

3 For example, see the Toronto Star article entitled "Former Palestinian fighter detained for months by PA security forces." Canadian journalist Jesse Rosenfeld reports the case of Zakaria Zubaidi, who was arrested by the PA on behalf of the Israeli military. Rosenfald writes, "Based on agreements stemming from the Oslo Accords, the PA forces are required to not interfere with Israeli raids on Palestinians in the Occupied Territories and to assist Israel and detain people the Israeli military considers a security threat. Popularly seen by Palestinians as Israel outsourcing occupation rule to the PA, there are increasing demands on the PA to stop all security coordination activities."

4 In $B D S$, Omar Barghouti notes the transformation of the Oslo peace process into a "peace industry," which assumes that the conflict is predicated on psychologically entrenched hatred between 
Palestinians and Israelis, rather than a structural system of asymmetry between the occupier and the occupied.

5 See Arthur Milner's introduction to Tro Plays About Israel/Palestine.

6 It is worth noting that Milner's response is based on post-show discussions that took place in Arabic. Various cast members and I translated the discussions for him. In this paper, I reflect on personal conversations and criticisms that I often received informally, not necessarily in the context of post-show talkback sessions.

7 For a brief description of the Goldstein Massacre, see Martin, The Sage Encyclopedia 232-33. Jason Sherman's play Reading Hebron addresses this massacre in theatrical form.

\section{Works Cited}

Al-Saber, Samer. "Director's Notes." Facts Production Program.” 26 Sept. 2012. Print.

Barghouti, Omar. BDS: Boycott, Divestment, Sanctions: the Global Struggle for Palestinian Rights. Chicago, Ill: Haymarket Books, 20II. Print.

Daley, Dan. "A Letter from a Canadian in Palestine." Praxistheatre.com. 6 Nov. 20II. Web. 25 May 2014. Hammack, Phillip L. Narrative and the Politics of Identity: The Cultural Psychology of Israeli and Palestinian Youth. New York: Oxford UP, 20Ir. Print

Jundi, Sami, and Jen Marlowe. The Hour of Sunlight: One Palestinian's fourney from Prisoner to Peacemaker. New York: Nation Books, 20II. Print.

Kershner, Isabel. "Spreading Palestinian Protests Focus on Leaders." New York Times II Sept. 2012, A6. Print.

Kotzamani, Marina. "Lysistrata on the Arabic Stage." PAF: A fournal of Performance and Art 28.2 (May 2006): 35. Print.

Martin, Gus, and Harvey W. Kushner. The Sage Encyclopedia of Terrorism. Thousand Oaks, Calif: SAGE Publications, 20Ir. Web. 25 May 2014.

Milner, Arthur. Two Plays About Israel/Palestine: Masada, Facts. S.1.: Iuniverse Inc, 2012. Print.

-. Final Report on Facts in Arabic Tour. Email. 22 Nov. 2012.

Rosenfeld, Jesse. "Former Palestinian fighter detained for months by PA security forces." Toronto Star. 28 Oct. 20I2. Web. 25 May 2014.

Sherman, Jason. Reading Hebron. Toronto: Hushion House, 1997. Print. 